\title{
ARTYKUŁY RECENZYJNE
}

\section{Krzysztof Gawlikowski}

\section{PIERWSZA W POLSCE HISTORIA TAJWANU}

Roman Sławiński, Historia Tajwanu, Dom Wydawniczy Elipsa, Warszawa 2001, ss. 208.

Jest to książka z pewnością bardzo potrzebna na naszym rynku czytelniczym, gdyż od 1990 r. o Tajwanie pisze się u nas i mówi bardzo dużo, a kontakty z nim bardzo się rozwinęły. Niestety wiedza o tej wyspie bywa często nikła, a bywają upowszechniane przez niektórych dziennikarzy nawet informacje zupełnie fantastyczne, jak opowieści o panującej tam - rzekomo - od półwiecza demokracji, czy o powszechnym pragnieniu niepodległości od Chin wyrażanym przez ludność tej wyspy i jej władze. Książka ukazuje zaś polityczne i gospodarcze realia, jak też skomplikowane dzieje Tajwanu. Jej autor zaś jest jednym z nielicznych polskich sinologów specjalizujących się w historii nowożytnej i najnowszej.

Książka ma charakter naukowy, aczkolwiek autor starał się napisać ją w sposób dość przystępny. Między innymi świadczą o tym tytuły krótkich rozdziałów typu: Tajwan: odległe poczatki; Europejczycy na Tajwanie; We władaniu rodu Cheng, itp. Przypisy i cały aparat naukowy są zredukowane do minimum. Czytelnik nie znajdzie tu zatem opisu kontrowersji naukowych dotyczących omawianych zagadnień, czy rozmaitych opinii na ich temat. Jest to zatem bardziej praca popularna niż klasyczne dzieło akademickie, choć solidna w sposób naukowy. Nie zawsze autor jest jednak konsekwentny i nieraz podaje dużo więcej szczegółów niż wymagałby taki rodzaj pracy. Na przykład wymienia wszystkich japońskich gubernatorów tej wyspy (z datami ich urzędowania!), co w takiej krótkiej syntezie może nieco dziwić. Często jednak obfitość szczegółów bardzo wzbogaca tę pracę, i czytelnik może być tylko wdzięczny, że autor tak często odstępuje od syntetycznego ujęcia. Wspomnieć trzeba, że stosuje on często używany na Tajwanie uproszczony system transkrypcji Wade-Gilesa, co dla osób przyzwyczajonych już do systemu pi- 
nyin może być nieco dezorientujące (choć zazwyczaj imiona znane podaje w nawiasie w tej ostatniej transkrypcji).

Autor zaczyna prezentację tej wyspy od opisu jej warunków przyrodniczych i historii jej zasiedlania - w czasach prehistorycznych przez jej pierwotnych, austronezyjskich mieszkańców, a od starożytności do XVII w. - przez Chińczyków. Tu także omawia nieco bardziej szczegółowo pozostałych do dzisiaj austronezyjskich mieszkańców tej wyspy (wszystko na s. 11-25). Następnie szkicuje historię odkrywania wyspy przez Europejczyków oraz nieudane próby jej podboju przez Holendrów i Hiszpanów w XVII w. (s. 26-35). Dalej autor relacjonuje barwne dzieje pirackiego rodu Chengów (Zhengów), który wypędził z niej cudzoziemców i utworzył tam rebelianckie, ,patriotyczne” państewko deklarujące wierność ostatnim potomkom obalonej już w istocie na kontynencie dynastii Ming (1368-1644). Zajęło to 6 stron. Opisuje dalej burzliwe koleje losu tej wyspy: podporządkowanie jej sobie przez mandżurską dynastię Qing (1683 r.); przejęcie jej w 1895 r. przez Japonię po wygranej wojnie z Chinami; próby stawienia oporu kolonizatorom (ze spektakularnym proklamowaniu tam republiki, choć deklarującej wierność dynastii mandżurskiej), co zajęło 25 stron. Omawia cokolwiek obszerniej japońskie panowanie na wyspie (do 1945 r.), i odzyskanie Tajwanu przez Chiny na mocy porozumień sojuszniczych, a w 1949 r., ucieczkę nań Czang Kai-szeka (Chiang Kai-sheka, Jiang Jieshi) z niedobitkami swojej armii i władzami obalonej Republiki Chińskiej. Całemu okresowi powojennemu, z zaprezentowaniem rozwoju gospodarczego Tajwanu, jego modernizacji, a także rozpoczętym pod koniec lat 80. procesom demokratyzacji - poświęca łącznie 70 stron. Krótkie Post scriptum szkicuje obecną sytuację międzynarodową tej wyspy, a przede wszystkim stosunki ze Stanami Zjednoczonymi i ChRL. Liczba stron poświęcona każdemu z okresów ilustruje, jak bardzo skrótowo relacjonuje ta praca niezmiernie skomplikowane wydarzenia i procesy.

Uzupełnia tę pracę Bibliografia (w której jednak nie znajdziemy wielu prac cytowanych w tekście, a za to sporo nie wspominanych nigdzie), indeksy, jak też w formie aneksów: bardzo krótką chronologię dziejów wyspy, tabele jej rozwoju gospodarczego, dość obszerną listą świąt obchodzonych na wyspie i uzupełnienia konstytucji z 1947 r. wprowadzone w latach ostatnich (w języku angielskim). W tekście pojawiają się fotografie czarno-białe (wykonane przez autora), niestety nędznej jakości, dość liczne tabele i zestawienia, a zamykają książkę barwne fotografie najwybitniejszych przywódców (z obecnym prezydentem i wiceprezydentem, co już może budzić pewne zdziwienie), trzy mapy wyspy oraz kilka innych fotografii z wyspy dobranych - chyba - nieco przypadkowo. Sympatyczna okładka i skromna, ale gustowna, szata graficzna - powodują, że bierze się tę książkę do ręki z przyjemnością.

Autor wykorzystał bardzo wiele opracowań w językach angielskim i chińskim, jak też inne źródła i materiały. Praca jest więc oparta na solidnych podstawach, acz napisana przystępnie. Przy tak krótkim wykładzie dziejów Tajwanu (łącznie 
152 strony) starczyło tam miejsca jedynie na zrelacjonowanie podstawowych faktów historycznych. Ich opis nie budzi istotniejszych wątpliwości, ani zastrzeżeń. Niewątpliwie ta synteza dziejów Tajwanu jest napisana umiejętnie i autor dążył do możliwie obiektywnego przedstawiania różnych, ostrych politycznie kwestii. Można jedynie zgłosić kilka drobnych zastrzeżeń: bardzo nieprecyzyjne i mylące jest stosowanie w tej pracy terminów „plemię” i „,szczep”, którymi autor szafuje w odniesieniu do aborygenów nie licząc się zupełnie z ich znaczeniami. Dziwne wrażenie robi używanie „spolszczonych” nazw różnych ludów. Na przykład lud nazywany Hakka (nazwa własna, używana też w języku angielskim), czy Kejia (ch.) określa się tu mianem „Hakkasów”. Prawdopodobnie autor poszedł tu śladem Maorysów, Papuasów, czy Zulusów. Wydaje się jednak lepszym pozostawianie takich nazw w formie oryginalnej i nieodmiennej. Jeśli zaś już koniecznie ktoś chciałby spolszczać nazwy chińskich ludów, to może lepiej byłoby skorzystać z innych form, typu Hakkijczyk, albo Hakkańczyk. Prof. M. J. Künstler stosuje formę Hakkowie, choć zazwyczaj traktuje ten wyraz jako nieodmienny ${ }^{1}$.

Czasami thumaczenia jakichś terminów chińskich bywają zaskakująco nieprecyzyjne, albo zdarzają się sformułowania nieodpowiednie. Np. kluczową zasadę dziewiętnastowieczną wyznaczającą stosunek władz cesarstwa do cywilizacji zachodniej, Xi wei Zhong yong, autor tłumaczy jako „Zachód w służbie Chin” (s. 56), podczas gdy powinno to być rozumiane jako: „zachodni [dorobek] stosować dla [praktycznego] wykorzystania go przez Chiny". Sens tego był bowiem taki, że jedynie to, co jest użyteczne w praktyce, jak nowe machiny, urządzenia, technologie, czy umiejętności, należy zapożyczać od cudzoziemców, zachowując tradycyjne chińskie wartości moralne, idee i zasady społeczne oraz polityczne ${ }^{2}$. W innym miejscu autor relacjonuje, jak to historyk z kontynentu pytany o przyczyny sukcesów gospodarczych miał odpowiedzieć: „Ch'ih k'u, dosłownie ,jedzenie gorzkiego” (ryżu), czyli nie tylko prosta pracowitość, ale także samozaparcie, gotowość do poświęceń bez narzekań i kwestionowania poleceń" (s. 160). Do pewnego stopnia ma rację, ale znowu nie jest do dobre objaśnienie. Obydwa terminy występujące w tym zwrocie mają o wiele bogatsze znaczenia. Termin ch'ih (chi) znaczy, co prawda, jeść, ale w języku chińskim jest stosowany bardzo szeroko, w rozmaitych metaforycznych znacze-

\footnotetext{
${ }^{1}$ Patrz jego Języki chińskie, Dialog, Warszawa 2000, s. 297-298.

${ }^{2}$ Jest to skrócona wersja zasady ujętej następująco: Zhong xue wei ti, Xi xue wei yong. Przethumaczyć ją można następująco: nauki chińskie traktować jako podstawowe [zasady], a nauki zachodnie wykorzystywać dla praktycznych zastosowań”. Sformułował ją Zhang Zhitong (1837-1909) w końcu XIX w. Patrz: Ssu-üy Teng, John K. Fairbank, China's response to the West, A documentary survey, 1839-1923, Harvard Unversity Press, Cambridge, Mass. 1981, s. 50, 164-174. „Nauki chińskie” utożsamiano z zasadami społecznymi i moralnymi (przede wszystkim z konfucjanizmem), a zachodnie $\mathrm{z}$ techniką, nowymi machinami, urządzeniami i umiejętnościami.
} 
niach, np. zlikwidować, wyczerpać, przyswoić sobie, znosić, albo cierpieć coś, itp³. Stąd jest wiele wyrażeń z tym czasownikiem odnoszących się do znoszenia, cierpienia czegoś z trudem. Z kolei $k^{\prime} u(k u)$ oznacza nie tylko ,gorzki” (w smaku), ale też przenośnie: trudności, cierpienie, ból; cierpieć coś (np. głód, biedę), znosić coś z trudem; wykonywać coś z trudem, oddając wszystkie siły; nazbyt ${ }^{4}$. Rozwiniętą formą tego wyrażenia jest chi kutou - znosić cierpienia, trudy ${ }^{5}$. Nie ma to zaś żadnego związku z ryżem. Oczywiście jest to drobiazg, ale dobremu znawcy języka chińskiego i Chin, jakim jest niewątpliwie autor, takie nieścisłości nie powinny się przydarzyć. Także sformułowania typu „w $1936 \mathrm{r}$. tj. w ostatnim poprzedzającym wybuch wojny antyjapońskiej w Chinach..." (s. 76) nie powinny się pojawić. Czy zaakceptowalibyśmy określenie „w 1938 r. na rok przed wybuchem walki z faszyzmem w Polsce", tak jakby wojnę zaczęli Polacy. Żeby był ruch oporu najpierw musi być najazd. Niedostatek pracy redakcyjnej jest, niestety, widoczny. Mimo tych drobnych niedostatków, jest to praca świetna, którą można polecić wszystkim interesującym się Azją Wschodnią.

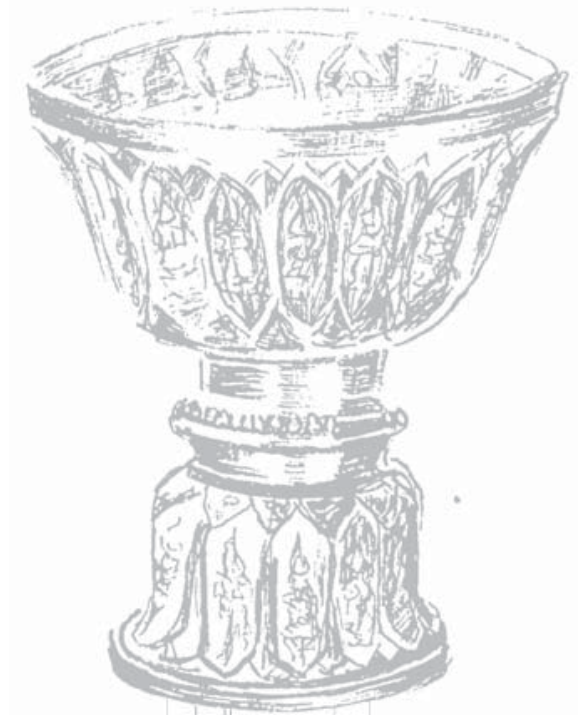

${ }^{3}$ Patrz np. The pinyin Chinese-English dictionary, Commercial Press, Kong 1984 (opracowany przez Beijing Yuyan Xueyuan), s. 89-90. Mathew's Chinese-English dictionary (Wenhua Tushu Gongsi, Taibei 1988) dodaje jeszcze: zużywać, holować i jąkać się (s. 145).

${ }^{4}$ The pinyin Chinese-English dictionary, cyt. wyd., s. 395.

${ }^{5}$ Ibidem, por. chi kutou, s. 90, i kutou, s. 395. 